(c) Lysanets Yu.V., Bieliaieva O.M., Slipchenko L.B., Havrylieva K.H., Morokhovets H.Yu.

UDC 811.111'42

DOI https://doi.org/10.31718/mep.2021.25.1-2.10

\title{
ESSENTIAL FEATURES OF EFFECTIVE ACADEMIC WRITING IN ENGLISH*
}

Lysanets Yu.V., Bieliaieva O.M., Slipchenko L.B., Havrylieva K.H., Morokhovets H.Yu.

Ukrainian Medical Stomatological Academy, Poltava, Ukraine

У статті розглянуто особливості наукового стилю англійської мови, спираючись на методичні рекомендації Британської Ради в Україні в рамках проєкту "Researcher Connect". Дослідження має на меті сприяти засвоєнню академічних стандартів англійської мови, мінімізації та уникненню помилок у писемному мовленні вітчизняних науковців. Автори окреслюють сучасні тенденції наукового стилю в англійській мові та надають рекомендації щодо досягнення максимального персуазивного ефекту при роботі з основними жанрами англомовного медичного дискурсу. Показано, що науковий стиль англійської мови наділений низкою специфічних лексико-граматичних принципів, дотримання яких забезпечує високу якість академічного письма. Водночас представлення результатів дослідження без урахування вищезгаданих норм наукового стилю англійської мови може призвести до помилок і непорозумінь у професійному середовищі, а також до низької якості англомовного медичного дискурсу, незважаючи на новизну, актуальність, теоретичну цінність і практичне значення отриманих результатів. Проаналізовано механізми вдосконалення навичок академічного письма під час вивчення англійської мови наукового спілкування, ураховуючи релевантні граматичні й лексичні особливості. Досліджено поверхневу та глибинну цілі основних жанрів наукового стилю і алгоритм складання профілю цільової аудиторії. Розглянуто механізми комунікативної стратегії переконання, принцип лаконічності в академічному письмі, а також граматичні й лексичні засоби їх реалізації. Автори наголошують, що розвиток комунікативних навичок українських дослідників і вивчення потенційних труднощів, 3 якими можуть зіткнутися медичні працівники при роботі з жанрами англомовного медичного дискурсу, мають вирішальне значення для успішного міжнародного спілкування і співпраці, усунення можливих помилок та уникнення непорозуміння у медичному середовищі. Подальше дослідження особливостей наукового стилю англійської мови сприятиме оптимізації міжнародної професійної комунікації, розширенню міжвідомчого діалогу та інтеграції України до світової спільноти.

Ключові слова: науковий стиль, англійська мова наукового спілкування, стратегія переконання, профіль цільової аудиторії, комунікативні навички, Британська Рада в Україні.

The article discusses the features of academic writing in English based on the recommendations from the British Council in Ukraine in the framework of the "Researcher Connect" project, aiming to facilitate the transition to academic standards of English and improve the academic discourse produced by non-native language users. The authors outline major tendencies in the modern English language as pertains to written discourse and provide recommendations for rendering academic writing persuasive. It is a well-established fact that academic writing in English possesses unique features, which must be respected and taken into account. Hence, a transfer of academic norms from a person's mother tongue to English can be a challenge, which may impair the quality of academic writing. Presenting the research results without consideration of academic norms, grammar, and lexical features of English academic writing can lead to mistakes and misunderstanding, and result in a written work of poor quality, even if the research findings are valid. The mechanisms of improving the academic writing skills during the study of English for Academic Communication with due account for relevant grammar and lexical peculiarities have been explored. Therefore, the major challenge for researchers is the difficulty in transition to academic standards of a foreign language. The article discusses the surface and the deeper purposes in any academic writing; the significance of understanding one's audience; the concepts of persuasion, clarity, and conciseness, as well as grammar and lexical means for achieving them. Developing the communication skills of Ukrainian scientists is crucial for successful international communication and cooperation. The study of potential difficulties, which the Ukrainian medical professionals may face in the process of academic writing in English, is important for developing the guidelines to eliminate possible mistakes and avoid misunderstanding in a medical setting. Further study of the peculiarities of academic writing in English will contribute to the optimization of international professional communication, the expansion of inter-institutional dialogue, and the integration of Ukraine into the world community.

Key words: academic writing, English for Academic Communication, the persuasion strategy, target audience profile, communicative skills, British Council in Ukraine.

The prevalence of English as not only the lingua franca but as an important transmission medium of scientific knowledge compels the professionals in all spheres to acquire "academic literacy" in the English language. Consequently, future specialists are expected to be not only fluent in English, but also well-versed in the style and standards of the English academic discourse [2; 4]. Hence, it is crucial to know the peculiarities of academic writing in English to be able to produce effective professional communication. Academic writing in each language possesses a number of unique features, which must be taken into account. It is well established that transfer of academic norms from a person's mother tongue to English can be a challenge, which may impair the quality of academic writing and speaking [5; 14]. Failure to conform to a specific academic style (among oth-

*To cite this English version: Lysanets Yu.V., Bieliaieva O.M., Slipchenko L.B., Havrylieva K.H., Morokhovets H.Yu. Essential features of effective academic writing in English // The Medical and ecological problems. - 2021. - Vol 25, № 1-2. - P. 41-43. 
ers) can create a bad impression on the reviewers and result in rejection, even if the research findings are valid. Therefore, the major challenge for researchers is the difficulty in transition to academic standards of a foreign language. This article aims to facilitate the transition to academic standards of English and improve the academic discourse, produced by non-native language users. Therefore, we will discuss: (1) some insights into the specific features, including relevant grammar and lexical features and norms of academic writing in English; (2) the tips for rendering academic writing persuasive; (3) the major tendencies in the modern English language as pertains to written discourse. The study of potential difficulties, which Ukrainian medical professionals may face in the process of academic writing in English, is important for developing the guidelines to eliminate possible mistakes and avoid misunderstanding in medical communication.

Before starting any piece of research, it is essential to define the purpose of academic writing. According to the Researcher Connect teaching framework, academic writing always embraces two types of purposes: the surface and the deeper one [13]. The surface purpose implies describing one's achievements in the area / sharing one's research findings with peers / getting a promotion at work / passing a credit test or an exam, etc. Meanwhile, the deeper purpose of academic writing is to persuade the audience of the significance of one's research, i.e., that one's essay is convincing / one's presentation is worth visiting the talk/one's article is worth downloading and reading the entire paper (i.e., to persuade them to read more than an abstract) [13].

Understanding the audience is yet another critical element of academic writing. In order to produce an effective persuasive discourse, the writer must understand the reader's perspective. It is necessary to bear in mind that the reader will scan research under the WIIFM principle: "What's In It For Me?" [13]. Therefore, a successful audience profile should adhere to the following algorithm:

1) Who are your readers (e.g., researchers, administrators, politicians, teachers, doctors, etc.)?

2) What the reader already knows.

3) What the reader needs to know: what should be included and what to read first.

4) What you want the reader to: know (e.g., to learn something new); think (of something new); do (e.g., convince them to attend your presentation at the conference or download and read the entire article; persuade them to perform certain actions as suggested and argued in your essay).

As one can observe, persuasion is a principal goal of any academic writing. The aim is to persuade the reader to accept the new knowledge claims. As people are not persuaded until they are convinced that something is true, the act of persuading involves showing how something is true or how it can be shown to be true [1]. For example, in the case of essay writing at universities, the purpose of a student's text is to convince the reader - the lecturer - that the assignment purpose has been achieved. Likewise, in a typical research article, each stage has its specific persuasive goal. The purpose of the introduction section is to convince the reader that the research is necessary and useful. The methods section aims to convince the reader that the research was done well. The purpose of the results section is to convince the reader that, for example, the statistical methods used were useful and informative. The discussion section is designed to convince the reader that the results make sense and contribute to a consistent body of knowledge [12].

At the prewriting phase of academic writing, it is essential to choose a position. For this purpose, it is necessary to think about the issue under consideration and to pick the side, which will be advocated. One should identify the most convincing evidence, as well as the key points for the opposing view. In this context, it is reasonable to follow the PEEP principle, which suggests structuring research according to the following sections: Point (i.e., the statement sentence), Evidence (referring to authoritative sources), Explanation (demonstrating how these sources pertain to the point of research), Point (restatement of the research claim) [13].

Furthermore, the $6 \mathrm{Cs}$ rule of academic writing is of particular importance: scientific communication has to be clear, concise, concrete, correct, coherent, and complete [13]. Let us focus on the conciseness principle as one of the cornerstones of academic writing. In fact, the Institute of Industrial Psychologists in the UK researched the link between readability and sentence length by asking 100 people to read three sentences once and checking the comprehension levels of each person [13]. The length of each sentence was 7, 17, and 27 words, whereas understanding at one reading was $96 \%, 75 \%$, and $4 \%$, respectively. Hence, researchers concluded that the maximum sentence length should be 20 words. The average length of a sentence should be $12-15$ words. The average paragraph length should be 8 lines for printed sources, and 4 lines for online sources [13].

It is necessary to bear in mind that the language of persuasion should always be implicit. That is to say, the participants of rhetorical persuasion must be eventually convinced that they have not been convinced at all. One of the ways to achieve this effect is by using strong and active language, which brings a confident attitude to academic writing. Using active language in academic writing helps to: stay direct and concise, get to the point, focus the readers' attention, achieve greater impact, and ultimately persuade your audience. In contrast, passive voice can be imprecise and confusing; it can slow the reader down and disrupt the sentence focus. Indeed, passive voice can weaken your writing and result in excessive wordiness, which may switch off the readers' attention. For example, cf.: The research statement has been supported by the focus group (Passive voice) / The focus group has supported the research statement (Active voice). As one can observe, the active voice sounds stronger, leaving no room for uncertainty. In general, the passive voice is used to describe a process, the results of the study, or similar material, which is objective, whereas active voice is used to describe actions. Therefore, it is usually appropriate to use a good balance of passive and active forms within academic writing. The choice of active/passive voice depends on the context. Clarity of meaning is paramount in research. The aim must be to avoid any possibility of confusion in the written and spoken meaning.

Another important aspect is the use of appropriate tenses in academic writing. In our previous study, we found that three tenses make up $98 \%$ of the tensed verbs used in academic writing [9]. The most common tense is present simple, followed by past simple and present perfect. These tenses can be used both in the passive and active voice. The present tense is appropriate for the Background or Introduction, as well as the Discussion 
section. The present perfect tense is mostly used for referring to previous research in the field and/or one's previous findings; it implies that the result is still true and relevant today. The actual research (the Methods and Results sections) is written in the past tense [9]. Diagrams and figures are described in Present simple tense. Meanwhile, the Conclusion section may usually contain a combination of tenses [12].

Other potential lexical challenges in academic writing include the use of paronyms (similar-sounding words with a partial coincidence of morphemic composition) [3]; "translator's false friends", also known as pseudointernationalisms (words in two languages that look or sound similar but have entirely different meanings) [10]; contronyms (words with two contradictory meanings) [11]; eponyms (terms derived from people's names) [6]; Latinderived terms [8] and spelling differences in British and US English [7].

Thus, academic writing in English has a number of unique features, which must be respected and taken into account. The deeper purpose of any academic writing is to persuade the audience of the significance of the author's research. Therefore, specific language tools must be selected and applied. In the process of writing in English, clarity and conciseness should be the major objectives, since they ensure the persuasiveness of the written discourse. Presenting the research results without consideration of academic norms, grammar, and lexical features of English academic writing can lead to mistakes and misunderstanding, and result in a written work of poor quality. It is crucial for professionals in all specialties to be aware of peculiarities of academic writing in English in order to be able to produce effective writing which will be accepted by peer-reviewed journals, to be understood and acknowledged, and ultimately to succeed in the modern English-speaking world.

\section{References}

1. Berezhanska Yu. V. Lingvostilistichni osoblyvosti persuazyvnogo medychnogo dyskursu, prysvyachenogo problemi evtanaziyi. Naukovi zapysky Nazional'nogo universytetu "Ostroz'ka akademiya". Seriya Filologichna: zbirnik naukovych prats'. Ostrog: Vydavnytstvo Nazional'nogo universytetu "Ostroz'ka akademiya". 2014; 44: 39-41.

2. Bieliaieva O., Lysanets Yu. Grammatical and lexical features of academic writing in English for medical students. Suchasni problemy humanitarystyky: svitohlyadni poshuky, komunikatyvni ta pedahohichni stratehiyi: materialy V Vseukr. nauk.-prakt. konf. (Rivne, 10 hrudnya 2015 r.). 2015; 233-235.
3. Bieliaieva O., Lysanets Yu., Havrylieva K. [et al.]. Paronymy in the Sublanguage of Medicine (Linguistic and Linguo-Didactic Aspects). Georgian Medical News. 2017; 10 (271): 144-149.

4. Frodesen J. Teaching English as a Second or Foreign Language (4th ed.) / [Eds. M. Celce-Murcia, D. Brinton, and M. Snow]. Boston: Heinle \& Heinle. 2014: 233-248.

5. Hinkel E. Research Findings on Teaching Grammar for Academic Writing. English Teaching. 2013; Vol. 68, No. 4: 3-21.

6. Lysanets Yu., Havrylieva K. Medical Eponyms as a Subject of Controversies in the Modern Terminology Studies. Aktual'ni problemy suchasnoyi medytsyny. 2017; 17, 4(60): 225-227.

7. Lysanets Yu., Bieliaieva O., Pisotska O. Professional Medical Discourse in British and American English: Spelling Differences. Naukovi za-piski Nazional'nogo universitetu "Ostroz'ka akademiya". Seriya Filologichna: zbirnik naukovich praz'. Ostrog: Vidavniztvo Nazional'nogo universitetu "Ostroz'ka akademiya". 2018; 1(69): $1251-$ 253.

8. Lysanets Yu., Bieliaieva O. The use of Latin terminology in medical case reports: quantitative, structural, and thematic analysis [Electronic resource]. Journal of Medical Case Reports. 2018; 12(45). - Access mode: https://doi.org/10.1186/s13256-018-1562-x

9. Lysanets Yu., Morokhovets H., Bieliaieva O. Stylistic Features of Case Reports as a Genre of Medical Discourse [Electronic resource]. Journal of Medical Case Reports. 2017; 11(83). - Access mode: https://doi.org/10.1186/s13256-017-1247-x

10. Lysanets Yu., Bieliaieva O., Nikolaiieva N. PseudoInternationalisms in the Language of Medicine and Healthcare as a Challenge for Translation Studies. Aktual'ni problemy romano-hermans'koyi filolohiyi ta prykladnoyi linhvistyky: naukovyi zhurnal / redkol. V. I. Kushneryk ta in. - Chernivtsi: Vydavnychyy dim «RODOVID». 2017; 2 (15): 46-49.

11. Lysanets Yu. V. Enantiosemiya $v$ anhlomovnomu medychnomu dyskursi. Aktual'ni problemy suchasnoyi medytsyny. 2014;14, 4(48): 256-259.

12. Pisotska O., Lysanets Yu., Bieliaieva O. Grammar Features of Academic Writing in Medical English: Tense Choice in Research Articles. Innovatsiyni tekhnolohiyi u konteksti inshomovnoyi pidhotovky fakhivtsya: materialy IV Mizhnarodnoyi nauk.-prakt. konf. (Poltava, 24 kvitnya 2018 r.). 2018: 93-97.

13. Researcher Connect: Participants Workbooks [Electronic resource]. British Council Development Centre. Access mode: https://www. britishcouncil.org/education/hescience/researcher-connect

14. Swales J., Feak C. Academic Writing for Graduate Students (3rd ed.). - Ann Arbor, MI: The University of Michigan Press, 2012; 344 p.

Матеріал надійшов до редакції 25.02.2021 